\title{
KEMAMPUAN KOMPETISI RELATIVE TEBU-PRG EVENT-5 TERHADAP GULMA DAUN SEMPIT DAN DAUN LEBAR MELALUI PENDEKATAN REPLACEMENT SERIES (RELATIVE COMPETITIVE ABILITY OF SUGARCANE EVENT-5 AND ITS PRIMARY WEEDS USING REPLACEMENT SERIES APPROACH)
}

\author{
Netty Ermawati $^{\left.{ }^{*}\right)}$, Nurmalasari ${ }^{2)}$, Novita Cholifah Ida ${ }^{1)}$, Bambang Sugiharto ${ }^{3)}$ \\ 1) Jurusan Produksi Pertanian \& UPT Lab. Biosains, Politeknik Negeri Jember, \\ JL. Mastrip Kotak Pos 164 Jember \\ 2) PT. Perkebunan Nusantara XI, Bidang PPU, Jl. Merak No.1 Surabaya \\ 3) Fakultas MIPA Universitas Jember, Jl. Kalimantan 23 Jember \\ *) Corresponding author: nettyermawati@yahoo.com
}

\begin{abstract}
Event-5 is a genetically modified (GM) sugarcane that engineered by introducing the Sucrose-Phosphate Synthase (SPS) gene to enhance the sugar productivity. To fulfill the security requirements of genetically modified products in the safety agriculture and the enviroment, it is necessary to test the competitive ability to the primary weeds which grow in the sugarcane cultivation areas. This study aimed to determine whether the transgenic sugarcane (Event-5) potentially invasive to the weeds at the critical stage of growth, that could effect the environmental balances. This research was conducted at Screen House and Laboratory for Biosciences, State Polytechnic of Jember, designed using the replacement series method in a Randomized Complete Block Design without factorial treatment. The combination treatments were Event-5, Nontransgenic sugarcane (NT) and the weeds (Ciperus rotundus and Portulaca olecarea) densities which consists of thirty-three treatments. The competitive ability test was determined by the rate of vegetative growth and the relative dry weight biomass of Event-5, NT plant and the weeds. The results indicated that the growth rate of Event-5, as well as the accumulation of dry weight of transgenic sugarcane were highly decrease than those of the weeds. The relative crowding coefficient (RCC) value of Event-5 showed lower compared to the $P$. olecarea weed, and sligtly higher to the $C$. rotundus weed. The RCC value of weed $(C$. rotundus) was higher than the RCC value of Event-5, suggested that the weed was potentially invasive to the transgenic sugarcane, and the Event-5 was not potential as a weed.
\end{abstract}

Key words: genetically modified, sugarcane, invasive, weed, replacement series

\section{PENDAHULUAN}

Pada sistem pertanaman, kompetisi adalah hubungan interaksi antara dua individu tanaman baik yang sejenis (intraspesifik) maupun berlainan jenis (interspesifik) yang dapat menimbulkan pengaruh negatif bagi keduanya sebagai akibat dari pemanfaatan sumber daya yang ada dalam keadaan terbatas secara bersama. Intraspesifik kompetisi menghasilkan hubungan timbal-balik yang linear antara hasil tanaman dan kepadatan tanaman. Sedangkan pada kompetisi interspesifik hasil ratarata setiap spesies adalah merupakan fungsi dari masing-masing komponen dari spesies yang ditanam (Walck, et a.l, 1999). Faktor yang menentukan tingkat kompetisi menurut Goldberg and Barton (1992) adalah kepadatan populasi, pola distribusi dan keragaman spesies. Dengan meningkatnya kepadatan populasi, maka gangguan yang ditimbulkan oleh tanaman yang satu terhadap tanaman yang lainnya akan semakin jelas dan meningkat. Tanaman menunjukkan keunggulan dalam berkompetisi jika kemampuan tumbuhnya meningkat, pertumbuhan setiap individunya cepat (baik pertumbuhan keatas maupun ke bawah) dalam membentuk akumulasi biomassa, pembentukan kanopi yang baik, mempunyai efisiensi dalam penggunaan air dan penyerapan unsur hara (Islam and Karim, 2003).

Metode penelitian yang digunakan secara luas untuk mempelajari kompetisi antara dua spesies tanaman adalah replacement series design yang dikembangkan oleh De Wit (1960) dan disederhanakan oleh Sitompul dan Guritno (1995). Metode ini juga digunakan untuk mengetahui kompetisi interspesifik antar tanaman budidaya dan atau gulma (Sandhi dan Guntoro, 2009; Wakck, et al., 1999), dan potensi invansif pada tanaman endemik dan eksotik (Utomo dkk., 2007; Awodoyin and Ogunyemi, 2008; Gioria and Bruce, 2014). Berdasarkan pada pendekatan metode tersebut, penelitian mengenai kemampuan 
kompetisi antara tebu-PRG (Produk Rekayasa Genetik) Event-5 terhadap gulma utama yang ada diarea pertanaman tebu ini dilakukan.

Secara alami tanaman tebu tidak berpotensi sebagai gulma, dan tanaman yang tidak direkayasa secara genetik tidak merupakan tanaman yang invasif dan tidak mempunyai potensi menjadi gulma (Riches and Valverder, 2002). Tebu PRG Event-5 merupakan klon terseleksi dari hasil rekayasa genetik overekspresi gen SPS (SucrosePhosphate Synthase) dengan tetua adalah varietas BL-579. Tebu transgenik SPS yang digunakan sebagai bahan pengujian dalam penelitian ini, telah melalui pengujian untuk alergenetis, toxicitan dan nutrisi. Sebelum pelepasan, persyaratan keamanan lingkungan mengharuskan untuk melakukan pengkajian keamanan produk hasil rekayasa genetik yang meliputi dampak terhadap organisme non target, dampak terhadap keanekaragaman hayati, perpindahan gen (gene flow), dan potensi menjadi gulma (weediness potential) (Riches and Valverder, 2002).

Menurut Kuntohartono (1987), gulma utama yang tumbuh diarea pertanaman tebu, yaitu gulma dari golongan berdaun sempit teki-tekian (Ciperus rotundus) dan gulma berdaun lebar yaitu krokot (Portulaca olecerea). Melalui sistem penanaman monokultur dan campuran antara tebu-PRG dengan gulma utamanya, maka kemampuan kompetisi antara keduanya akan dapat diketahui. Tujuan penelitian ini adalah untuk mengkaji potensi invasif atau kemampuan kompetisi tebu PRG Event-5 terhadap gulma dan potensinya untuk menjadi gulma melalui pendekatan metode replacement series.

\section{METODOLOGI}

\section{Bahan dan Alat}

Bahan yang digunakan meliputi: bagal tebu dengan 1 mata (budchip) dari tebu PRG varietas BL-SPS (Event-5) dan bagal 1 mata dari varietas induk (BL-579) yang digunakan sebagai kontrol, media tanam berupa tanah yang telah diayak, gulma berdaun sempit; teki (C. rotundus), dan gulma berdaun lebar; pegagang/krokot $(P$. olecerea). peralatan yang digunakan meliputi: pot dengan diameter $30 \mathrm{~cm}$, meteran, timbangan (Ohaus), oven (Binder, Germany), alat tulis, serta peralatan budidaya lainnya.

\section{Persiapan Penanaman dan Pengambilan Sampel}

Media dipersiapkan dari tanah sawah yang digemburkan terlebih dahulu menggunakan cangkul, kemudian dikeringkan dan diayak untuk menghilangkan gulma yang tertinggal dan ada ditanah. Kemudian tanah dimasukkan kedalam pot seberat $9 \mathrm{~kg} /$ pot. Bahan tanam dipersiapkan dari bagal tebu yang telah memiliki mata tunas dengan panjang $\pm 5 \mathrm{~cm}$ diambil dari persemaian, gulma teki dengan stolonnya dan gulma krokot dengan akarnya, masing-masing dipotong dengan panjang $\pm 3 \mathrm{~cm}$ dari pangkal batang, kemudian dipindah tanam ke dalam pot. Kombinasi populasi jenis tebu dan atau jenis gulma ditanam dalam pot-pot sesuai perlakuan yaitu : 0, 3, 6, 9 dan 12 tanaman per pot. Untuk penyulaman dilakukan apabila populasi dalam pot ada yang mati (busuk) setelah 7 hari penanaman.

Pemeliharaan meliputi penyiangan gulma non target, penyiraman, pemupukan, pengendalian hama penyakit, dan pembumbunan. Pengamatan tanaman dilakukan secara bertahap yaitu setiap 14 hari sekali, meliputi tinggi tanaman, jumlah anakan dan berat kering tanaman tebu dan gulma. Pemanenan dilakukan setelah tanaman berumur 70 hari setelah tanam (HST) dengan memisahkan tanaman tebu dan gulma untuk jenis penanaman

Tabel 1. Kombinasi kepadatan tanaman tebu dan jenis gulmanya.

\begin{tabular}{ccccccccccc}
\hline & & \multicolumn{1}{c}{ Jumlah Kombinasi bibit / pot } \\
\hline $\mathrm{A}_{1} \mathrm{X}_{0}$ & $\mathrm{~A}_{2} \mathrm{X}_{0}$ & $\mathrm{~A}_{3} \mathrm{X}_{0}$ & $\mathrm{~A}_{4} \mathrm{X}_{0}$ & $\mathrm{~A}_{0} \mathrm{X}_{1}$ & $\mathrm{~A}_{0} \mathrm{X}_{2}$ & $\mathrm{~A}_{0} \mathrm{X}_{3}$ & $\mathrm{~A}_{0} \mathrm{X}_{4}$ & $\mathrm{~A}_{1} \mathrm{X}_{3}$ & $\mathrm{~A}_{2} \mathrm{X}_{2}$ & $\mathrm{~A}_{3} \mathrm{X}_{1}$ \\
$3: 0$ & $6: 0$ & $9: 0$ & $12: 0$ & $0: 3$ & $0: 6$ & $0: 9$ & $0: 12$ & $3: 9$ & $6: 6$ & $9: 3$ \\
\hline $\mathrm{A}_{1} \mathrm{Y}_{0}$ & $\mathrm{~A}_{2} \mathrm{Y}_{0}$ & $\mathrm{~A}_{3} \mathrm{Y}_{0}$ & $\mathrm{~A}_{4} \mathrm{Y}_{0}$ & $\mathrm{~A}_{0} \mathrm{Y}_{1}$ & $\mathrm{~A}_{0} \mathrm{Y}_{2}$ & $\mathrm{~A}_{0} \mathrm{Y}_{3}$ & $\mathrm{~A}_{0} \mathrm{Y}_{4}$ & $\mathrm{~A}_{1} \mathrm{Y}_{3}$ & $\mathrm{~A}_{2} \mathrm{Y}_{2}$ & $\mathrm{~A}_{3} \mathrm{Y}_{1}$ \\
$3: 0$ & $6: 0$ & $9: 0$ & $12: 0$ & $0: 3$ & $0: 6$ & $0: 9$ & $0: 12$ & $3: 9$ & $6: 6$ & $9: 3$ \\
\hline $\mathrm{A}: \mathrm{NT}$ & $\mathrm{A}: \mathrm{NT}$ & $\mathrm{A}: \mathrm{NT}$ & $\mathrm{A}: \mathrm{NT}$ & $\mathrm{A}: \mathrm{NT}$ & $\mathrm{A}: \mathrm{NT}$ & $\mathrm{A}: \mathrm{NT}$ & $\mathrm{A}: \mathrm{NT}$ & $\mathrm{A}: \mathrm{NT}$ & $\mathrm{A}: \mathrm{NT}$ & $\mathrm{A}: \mathrm{NT}$ \\
$3: 0$ & $6: 0$ & $9: 0$ & $12: 0$ & $0: 3$ & $0: 6$ & $0: 9$ & $0: 12$ & $3: 9$ & $6: 6$ & $9: 3$ \\
\hline
\end{tabular}

Keterangan: A; tebu Event-5, NT; tebu non-transgenik, X; gulma teki, Y; gulma krokot. Notasi angka yang tertera dibawah kombinasi perlakuan adalah jumlah populasi tebu/gulma yang digunakan.

campuran, setelah itu dikeringkan menggunakan oven pengering dengan suhu $80^{\circ} \mathrm{C}$ selama 98 jam atau sampai diperoleh berat konstan.

\section{Metode Percobaan}

Percobaan dilakukan dengan menggunakan Rancangan Acak Kelompok (RAK) non faktorial. Untuk masing-masing kelompok percobaan, dua jenis tebu dan atau dengan kombinasi gulma ditanam pada pot-pot sesuai perlakuan yaitu: 0,3 , 6, 9 dan 12 tanaman per pot, yang disusun menurut metode rangkaian substitusi/replacement series (Tabel 1), meliputi 33 perlakuan dengan 3 ulangan, sehingga terdapat 99 unit percobaan. Data hasil pengamatan untuk tinggi tanaman dan jumlah anakan dianalisis dengan menggunakan analisis 
ragam taraf 5\%. Apabila hasil analisis ragam menunjukkan perbedaan nyata, dilakukan uji lanjut dengan DMRT (Duncan Multiple Range Test) pada taraf $5 \%$.

\section{Pengukuran tinggi tanaman dan jumlah anakan}

Tinggi tanaman diukur mulai dari leher akar (permukaan tanah hingga ke ujung daun tertinggi), setiap interval 14 hari sampai dengan umur 70 hari setelah tanam (HST) dengan menggunakan mistar. Sedangkan jumlah anakan, dihitung setiap interval 14 hari sampai dengan umur 70 hari setelah tanam (HST).

\section{Koefisien Kesesakan Relative (Relative Crowding coefficient)}

Untuk mengkaji persaingan (daya kompetisi yang terjadi, dilakukan perhitungan koefisien kesesakan relative (Relative Crowding coefficient) berdasarkan berat kering tanaman menurut formula yang dikembangkan oleh De Wit (1960) dan disederhanakan oleh Sitompul dan Guritno (1995):

$$
K_{a b}=\frac{Y_{a b} \times Z_{b a}}{\left(Y_{a a}-Y_{a b}\right) Z_{a b}}
$$

Dimana:

$\mathrm{K}_{\mathrm{ab}}=$ koefisien kesesakan relative tanaman tebu (a) terhadap gulma (b)

$\mathrm{Y}_{\mathrm{aa}}=$ bobot kering dari tanaman tebu dalam sistem monokultur

$\mathrm{Y}_{\mathrm{ab}}=$ bobot kering tanaman tebu dalam sistem campuran dengan gulma

$\mathrm{Z}_{\mathrm{ab}}=$ proporsi penanaman tebu terhadap gulma dalam sistem campuran

$\mathrm{Z}_{\mathrm{ba}}=$ proporsi penanaman jenis gulma terhadap tanaman tebu dalam sistem campuran

\section{HASIL DAN PEMBAHASAN}

Kompetisi pada suatu area penanaman ditunjukkan oleh adanya suatu interaksi di mana dua individu atau lebih bersaing untuk mendapatkan nutrisi, tempat hidup, cahaya dan lainnya yang kondisinya dalam keadaan terbatas. Pada tanaman, kompetisi bisa terjadi sejak awal pertumbuhan, semakin dewasa tanaman maka tingkat kompetisinya akan meningkat hingga suatu saat akan mencapai klimak dan kemudian menurun secara bertahap (Owodoyin and Ogunyemi, 2008). Kompetisi yang mengarah pada invasi tidak hanya mengakibatkan berkurangnya pertumbuhan, namun dapat memberi dampak komplek pada level ekologi, dari gen sampai pada ekosistem (Mark, et. al., 2000).

Pada penelitian ini, potensi invasif dari tebu transgenik Event-5 terhadap dua gulma utamanya dan juga terhadap tebu Non-transgenik dianalisis dari tingkat pertumbuhan dan pertambahan volume pada sistem tanam yang berbeda dan koefisien kesesakan relatif dari sistem tanam campuran pada masing-masing perlakuan.

\section{Pengaruh Sistem Tanam, Populasi Event-5 dan Gulma terhadap Tinggi Tebu Event-5}

Sistem tanam dan populasi sangat menentukan laju pertumbuhan tanaman. Hal ini ditunjukkan oleh parameter tinggi tanaman tebu Event-5, Non Transgenik (NT) dan jenis gulma yang ditanam secara monokultur dan campuran dengan tingkat kepadatan populasi yang berbeda (Tabel 1).

Pengaruh populasi tebu Event-5 dan gulmanya terhadap pertambahan tinggi tebu Event-5, ditunjukkan pada Tabel 2 dan Tabel 3. Pengaruh populasi tebu Event-5 dan gulma terhadap tinggi tebu Event-5 dianalisa dari selisih pertumbuhan tinggi tanaman pada setiap pengamatan, yang meliputi 5 tahap pengamatan yaitu pada 0-14 HST, 14-28 HST, 28-42 HST, 42-56 HST, dan 56-70 HST. Hasil analisis sidik ragam menunjukkan bahwa pertambahan tinggi tebu Event-5 yang ditanam secara monokultur lebih cepat dibandingkan dengan Event-5 yang ditanam secara campuran dengan gulma teki dan krokot (Tabel 2 dan 3).

Populasi Event-5 berpengaruh tidak nyata terhadap tinggi tebu Event-5 sampai umur 28 HST. Pada saat tanaman Event-5 ditanam dengan sistem campuran dengan gulma teki, pada umur 28-42 HST (perlakuan A1X3, A2X2 dan A3X1), menunjukkan penurunan pertumbuhan tinggi tebu Event-5 berturut-turut sebesar $56 \%, 71 \%$ dan $48.4 \%$ dibandingkan dengan penanaman monokulturnya (Tabel 2). Namun pada saat akhir pengamatan (56-70 HST), pertumbuhan tinggi tanaman tebu Event-5 yang ditanam secara monokultur nampak mengalami penurunan dibandingkan dengan sistem tanam campuran. Perlakuan populasi gulma teki dan tebu Event-5 yang ditanam pada sistem campuran juga menekan pertambahan tinggi gulma teki pada 28-42 HST, perlakuan A1X3, A2X2 dan A3X1 dengan penurunan pertumbuhan berturut-turut sebesar 39.26\%, 70.44\% dan 60.46\% (Tabel 2). Pada perlakuan A3Y1 (Event-5 dan gulma krokot), pada 28-42 HST memberikan pengaruh pada penurunan tinggi tanaman sebesar $12.23 \%$. Namun demikian perlakuan populasi ini berpengaruh tidak nyata pada tinggi tanaman tebu Event-5 maupun gulma krokot pada akhir masa pengamatan (Tabel 3).

Tabel 2. Pengaruh Populasi Tebu Event-5 (A) dan Gulma Teki (X) terhadap Rata-rata Tinggi Tebu Event-5. 


\begin{tabular}{clllll}
\hline \multirow{3}{*}{ Perlakuan } & \multicolumn{5}{c}{ Rerata Tinggi Tanaman $(\mathbf{c m})$} \\
\cline { 2 - 6 } & $\mathbf{0 - 1 4}$ & $\mathbf{1 4 - 2 8}$ & $\mathbf{2 8 - 4 2}$ & $\mathbf{4 2 - 5 6}$ & $\mathbf{5 6 - 7 0}$ \\
& HST & HST & HST & HST & HST \\
\hline $\mathbf{A}_{\mathbf{1}}$ & 40.45 & 39.18 & $36.80 \mathrm{a}$ & 19.39 & $19.15 \mathrm{~d}$ \\
\hline $\mathbf{A}_{\mathbf{2}}$ & 37.17 & 34.13 & $49.63 \mathrm{~b}$ & 17.51 & $19.21 \mathrm{~d}$ \\
\hline $\mathbf{A}_{\mathbf{3}}$ & 35.04 & 34.70 & $32.48 \mathrm{~b}$ & 18.15 & $18.86 \mathrm{~d}$ \\
\hline $\mathbf{A}_{\mathbf{4}}$ & 35.94 & 33.81 & $29.52 \mathrm{~b}$ & 19.58 & $12.13 \mathrm{e}$ \\
\hline $\mathbf{A}_{\mathbf{1}} \mathbf{X}_{\mathbf{3}}$ & 43.21 & 22.50 & $16.17 \mathrm{e}$ & 24.60 & $25.23 \mathrm{c}$ \\
\hline $\mathbf{A}_{\mathbf{2}} \mathbf{X}_{\mathbf{2}}$ & 34.07 & 22.57 & $14.21 \mathrm{~d}$ & 23.16 & $32.82 \mathrm{a}$ \\
\hline $\mathbf{A}_{\mathbf{3}} \mathbf{X}_{\mathbf{1}}$ & 33.81 & 26.96 & $16.74 \mathrm{c}$ & 20.58 & $32.19 \mathrm{~b}$ \\
\hline
\end{tabular}

Keterangan : Angka-angka yang diikuti huruf yang sama pada kolom yang sama, berbeda tidak nyata pada uji DMRT 5\%.

Tabel 3. Pengaruh Populasi Tebu Event-5 (A) dan Gulma Krokot (Y) terhadap Rata-rata Tinggi Tebu Event-5.

\begin{tabular}{clllll}
\hline \multirow{2}{*}{ Perlakuan } & \multicolumn{5}{c}{ Rerata Tinggi Tanaman $(\mathbf{c m})$} \\
\cline { 2 - 6 } & $\mathbf{0 - 1 4}$ & $\mathbf{1 4 - 2 8}$ & $\mathbf{2 8 - 4 2}$ & $\mathbf{4 2 - 5 6}$ & $\mathbf{5 6 - 7 0}$ \\
& HST & HST & HST & HST & HST \\
\hline $\mathbf{A}_{\mathbf{1}}$ & 40.31 & $37.62 \mathrm{a}$ & $65.27 \mathrm{~b}$ & $16.39 \mathrm{c}$ & 29.85 \\
\hline $\mathbf{A}_{\mathbf{2}}$ & 40.21 & $33.02 \mathrm{~b}$ & $56.62 \mathrm{c}$ & $22.52 \mathrm{~b}$ & 28.43 \\
\hline $\mathbf{A}_{\mathbf{3}}$ & 34.87 & $32.22 \mathrm{~b}$ & $53.97 \mathrm{c}$ & $21.06 \mathrm{~b}$ & 36.24 \\
\hline $\mathbf{A}_{\mathbf{4}}$ & 39.29 & $29.80 \mathrm{~b}$ & $53.54 \mathrm{c}$ & $17.40 \mathrm{c}$ & 24.05 \\
\hline $\mathbf{A}_{\mathbf{1}} \mathbf{Y}_{\mathbf{3}}$ & 45.08 & $25.64 \mathrm{c}$ & $66.87 \mathrm{a}$ & $18.90 \mathrm{c}$ & 34.38 \\
\hline $\mathbf{A}_{\mathbf{2}} \mathbf{Y}_{\mathbf{2}}$ & 35.69 & $20.06 \mathrm{~d}$ & $54.10 \mathrm{c}$ & $24.56 \mathrm{a}$ & 36.78 \\
\hline $\mathbf{A}_{\mathbf{3}} \mathbf{Y}_{\mathbf{1}}$ & 37.59 & $20.72 \mathrm{~d}$ & $47.37 \mathrm{~d}$ & $26.61 \mathrm{a}$ & 35.81 \\
\hline
\end{tabular}

Keterangan : Angka-angka yang diikuti huruf yang sama pada kolom yang sama, berbeda tidak nyata pada uji DMRT 5\%.

\section{Pengaruh Sistem Tanam, Populasi Event-5 dan} Gulma terhadap Jumlah Anakan Tebu Event-5

Pengaruh populasi tebu Event-5 dan gulmanya terhadap jumlah anakan tebu Event-5 dianalisa dari selisih pertambahan jumlah anakan pada setiap pengamatan, yang meliputi 5 tahap pengamatan yaitu pada 14 HST, 28 HST, 42 HST, 56 HST, dan 70 HST.

Dari hasil analisis menunjukkan bahwa hubungan antara jumlah anakan dan umur tanaman yang ditanam baik secara monokultur atau campuran terus meningkat dengan cepat sampai umur 42 HST, dan mengalami penurunan penambahan jumlah anakan setelah 42 HST (Data tidak ditunjukkan). Perbedaan pertumbuhan jumlah anakan nampak jelas pada 42 HST, baik pada tebu Event-5 maupun gulma teki. Pertambahan jumlah anakan pada gulma teki lebih cepat jika dibandingkan dengan tebu Event-5. Untuk gulma krokot sampai pada akhir pengamatan, tidak menunjukkan pertambahan jumlah anakan.

Hasil analisis sidik ragam menunjukkan bahwa perlakuan populasi tebu Event-5 dan gulma teki berpengaruh tidak nyata terhadap jumlah anakan tebu maupun gulma teki. Namun demikian pada 42 HST, perlakuan $\mathrm{A} 1 \mathrm{X} 3$ dan $\mathrm{A} 2 \mathrm{X} 2$ menurunkan jumlah anakan tebu sebesar $72.4 \%$ dan $78 \%$. Penurunan terbesar terjadi pada perlakuan A1X3 pada 42 HST, 52 HST dan 70 HST, dibandingkan dengan sistem tanam monokulturnya (Tabel 4). Sedangkan hasil analisa sidik ragam antara populasi tebu dan gulma krokot terhadap jumlah anakan tebu Event-5 menunjukkan hasil berbeda nyata pada akhir pengamatan (70 HST), yaitu terjadi penurunan jumlah anakan jika dibandingkan dengan monokulturnya. Hasil ini menunjukkan terjadinya kompetisi interspesifik antara Event-5 dan gulma yang mengakibatkan tertekannya pertumbuhan dan jumlah anakan kedua tanaman tersebut (Tabel 5). Sedangkan untuk gulma krokot, sampai pengamatan terakhir tidak menunjukkan terbentuknya anakan.

Tabel 4. Pengaruh Populasi Tebu Event-5 (A) dan Gulma Teki (X) terhadap Rata-rata Jumlah Anakan Tebu Even-5.

\begin{tabular}{clllll}
\hline \multirow{3}{*}{ Perlakuan } & \multicolumn{5}{c}{ Rerata Jumlah Anakan } \\
\cline { 2 - 6 } & $\mathbf{1 4}$ & $\mathbf{2 8}$ & $\mathbf{4 2}$ & $\mathbf{5 6}$ & $\mathbf{7 0}$ \\
& HST & HST & HST & HST & HST \\
\hline $\mathbf{A}_{\mathbf{1}}$ & 0.00 & 2.89 & $8.44 \mathrm{a}$ & $9.11 \mathrm{a}$ & $10.44 \mathrm{a}$ \\
\hline $\mathbf{A}_{\mathbf{2}}$ & 0.00 & 2.61 & $6.06 \mathrm{ab}$ & $6.11 \mathrm{ab}$ & $6.17 \mathrm{~b}$ \\
\hline $\mathbf{A}_{\mathbf{3}}$ & 0.00 & 2.63 & $4.59 \mathrm{bc}$ & $5.11 \mathrm{~b}$ & $5.65 \mathrm{~b}$ \\
\hline $\mathbf{A}_{\mathbf{4}}$ & 0.00 & 1.92 & $3.86 \mathrm{bc}$ & $4.19 \mathrm{~b}$ & $5.34 \mathrm{~b}$ \\
\hline $\mathbf{A}_{\mathbf{1}} \mathbf{X}_{\mathbf{3}}$ & 0.00 & 1.44 & $2.33 \mathrm{c}$ & $5.56 \mathrm{~b}$ & $7.11 \mathrm{~b}$ \\
\hline $\mathbf{A}_{\mathbf{2}} \mathbf{X}_{\mathbf{2}}$ & 0.00 & 1.00 & $1.33 \mathrm{c}$ & $3.67 \mathrm{~b}$ & $5.17 \mathrm{~b}$ \\
\hline $\mathbf{A}_{\mathbf{3}} \mathbf{X}_{\mathbf{1}}$ & 0.00 & 0.96 & $2.11 \mathrm{c}$ & $3.48 \mathrm{~b}$ & $5.15 \mathrm{~b}$ \\
\hline
\end{tabular}

Keterangan: Angka-angka yang diikuti huruf yang sama pada kolom yang sama, berbeda tidak nyata pada uji DMRT 5\%.

Tabel 5. Pengaruh Populasi Tebu Event-5 (A) dan Gulma Krokot (Y) terhadap Rata-rata Jumlah Anakan Tebu Event-5.

\begin{tabular}{clllll}
\hline & \multicolumn{5}{c}{ Rerata Jumlah Anakan } \\
\cline { 2 - 6 } Perlakuan & $\mathbf{1 4}$ & $\mathbf{2 8}$ & $\mathbf{4 2}$ & $\mathbf{5 6}$ & $\mathbf{7 0}$ \\
& HST & HST & HST & HST & HST \\
\hline $\mathbf{A}_{\mathbf{1}}$ & 0.00 & 3.22 & $6.78 \mathrm{a}$ & $9.11 \mathrm{a}$ & $10.00 \mathrm{a}$ \\
\hline $\mathbf{A}_{\mathbf{2}}$ & 0.00 & 3.05 & $6.34 \mathrm{a}$ & $6.41 \mathrm{ab}$ & $6.41 \mathrm{bc}$ \\
\hline $\mathbf{A}_{3}$ & 0.00 & 2.26 & $3.85 \mathrm{ab}$ & $4.26 \mathrm{~b}$ & $4.26 \mathrm{c}$ \\
\hline $\mathbf{A}_{\mathbf{4}}$ & 0.00 & 2.25 & $3.94 \mathrm{ab}$ & $4.06 \mathrm{~b}$ & $4.06 \mathrm{c}$ \\
\hline $\mathbf{A}_{\mathbf{1}} \mathbf{Y}_{\mathbf{3}}$ & 0.00 & 1.89 & $2.22 \mathrm{~b}$ & $5.00 \mathrm{~b}$ & $8.22 \mathrm{ab}$ \\
\hline $\mathbf{A}_{\mathbf{2}} \mathbf{Y}_{\mathbf{2}}$ & 0.00 & 0.44 & $0.72 \mathrm{~b}$ & $4.17 \mathrm{~b}$ & $4.95 \mathrm{bc}$ \\
\hline $\mathbf{A}_{\mathbf{3}} \mathbf{Y}_{\mathbf{1}}$ & 0.00 & 0.89 & $1.29 \mathrm{~b}$ & $3.67 \mathrm{~b}$ & $4.48 \mathrm{c}$ \\
\hline
\end{tabular}

Keterangan : Angka-angka yang diikuti huruf yang sama pada kolom yang sama, berbeda tidak nyata pada uji DMRT 5\%.

Pengaruh Sistem Tanam, Populasi Event-5 dan Tebu Non-Transgenik terhadap Tinggi Tanaman dan Jumlah Anakan Event-5

Pertumbuhan tebu Event-5 yang ditanam secara monokultur dan campuran dengan tebu Non-transgenik dapat ditunjukkan dari laju pertambahan tinggi tanaman yang berbanding lurus dengan umur tanaman (Data tidak ditunjukkan). Laju pertumbuhan tebu Event-5 yang ditanam secara monokultur maupun campuran dengan tebu Non-transgenik menunjukkan berbeda tidak nyata, yang berarti bahwa adanya tebu Nontransgenik pada sistem penanaman campuran tidak menekan pertumbuhan tebu Event-5, begitu pula sebaliknya.

Untuk mengetahui pengaruh populasi tebu Event-5 dan tebu Non-transgenik terhadap tinggi tanaman dan jumlah anakan dilakukan analisis sidik ragam yang ditunjukkan pada Tabel 6 dan 7 . Hasil analisis menunjukkan bahwa populasi 
berpengaruh terhadap tinggi tanaman tebu Event-5 pada umur 56-70 HST. Penanaman dengan sistem campuran pada perlakuan A1NT3, A2NT2 dan A3NT1 antara tebu Event-5 dan Non-transgenik menurunkan tinggi tebu Event-5 berturut-turut sebesar $39.5 \%, 37.2 \%$ dan $38.65 \%$ dibandingkan dengan sistem tanam monokultur (Tabel 6). Penurunan tinggi tebu ini dimungkinkan bukan merupakan pengaruh dari kepadatan populasi, karena data dari jumlah anakan menunjukkan bahwa antara monokultur dan sistem campuran mempunyai rata-rata jumlah anakan yang sama (Tabel 7). Pada penanaman tebu Non-Transgenik dengan tebu Event-5 dengan sistem campuran perlakuan A3NT1 menunjukkan penurunan tinggi tebu Non-Transgenik sebesar $12 \%$ pada $28-42$ HST. Penanaman secara campuran secara keseluruhan antara tebu Event-5 dan Nontransgenik menurunkan jumlah anakan tebu Nontransgenik (Tabel 7). Kepadatan populasi memberikan pengaruh tidak nyata terhadap jumlah anakan kedua jenis tanaman tebu, penurunan jumlah anakan lebih disebabkan oleh adanya kompetisi intraspesifik antar kedua jenis tanaman tebu.

Tabel 6. Pengaruh Populasi Tebu Event-5 (A) dan Tebu Non-Transgenik (NT) terhadap rata-rata Tinggi Event-5.

\begin{tabular}{clllll}
\hline \multirow{3}{*}{ Perlakuan } & \multicolumn{5}{c}{ Rerata Tinggi Tanaman $(\mathbf{c m})$} \\
\cline { 2 - 6 } & $\mathbf{0 - 1 4}$ & $\mathbf{1 4 - 2 8}$ & $\mathbf{2 8 - 4 2}$ & $\mathbf{4 2 - 5 6}$ & $\mathbf{5 6 - 7 0}$ \\
& HST & HST & HST & HST & HST \\
\hline $\mathbf{A}_{\mathbf{1}}$ & 47.80 & $27.15 \mathrm{a}$ & $44.36 \mathrm{bc}$ & $12.08 \mathrm{a}$ & $32.52 \mathrm{a}$ \\
\hline $\mathbf{A}_{\mathbf{2}}$ & 39.34 & $23.20 \mathrm{~b}$ & $49.62 \mathrm{a}$ & $10.42 \mathrm{a}$ & $30.42 \mathrm{a}$ \\
\hline $\mathbf{A}_{\mathbf{3}}$ & 37.28 & $19.12 \mathrm{c}$ & $46.74 \mathrm{~b}$ & $11.85 \mathrm{a}$ & $29.88 \mathrm{a}$ \\
\hline $\mathbf{A}_{\mathbf{4}}$ & 35.28 & $18.12 \mathrm{c}$ & $49.74 \mathrm{a}$ & $5.71 \mathrm{~b}$ & $24.63 \mathrm{~b}$ \\
\hline $\mathbf{A}_{\mathbf{1}} \mathbf{N T}_{\mathbf{3}}$ & 30.47 & $29.63 \mathrm{a}$ & $45.07 \mathrm{bc}$ & $11.84 \mathrm{a}$ & $19.67 \mathrm{c}$ \\
\hline $\mathbf{A}_{\mathbf{2}} \mathbf{N T}_{\mathbf{2}}$ & 33.71 & $18.39 \mathrm{c}$ & $52.53 \mathrm{a}$ & $9.60 \mathrm{a}$ & $19.10 \mathrm{c}$ \\
\hline $\mathbf{A}_{\mathbf{3}} \mathbf{N T}_{\mathbf{1}}$ & 34.33 & $24.90 \mathrm{~b}$ & $42.03 \mathrm{c}$ & $11.95 \mathrm{a}$ & $18.33 \mathrm{c}$ \\
\hline
\end{tabular}

Keterangan : Angka-angka yang diikuti huruf yang sama pada kolom yang sama, berbeda tidak nyata pada uji DMRT 5\%.

Tabel 7. Pengaruh Populasi Tebu Event-5 (A) dan Tebu Non-Transgenik (NT) terhadap Rata-rata Jumlah Anakan Tebu Event-5.

\begin{tabular}{clllll}
\hline \multirow{2}{*}{ Perlakuan } & \multicolumn{5}{c}{ Rerata Jumlah Anakan } \\
\cline { 2 - 6 } & $\mathbf{1 4}$ & $\mathbf{2 8}$ & $\mathbf{4 2}$ & $\mathbf{5 6}$ & $\mathbf{7 0}$ \\
& HST & HST & HST & HST & HST \\
\hline $\mathbf{A}_{\mathbf{1}}$ & 0.00 & $3.55 \mathrm{a}$ & $7.56 \mathrm{ab}$ & $9.78 \mathrm{a}$ & $9.89 \mathrm{a}$ \\
\hline $\mathbf{A}_{\mathbf{2}}$ & 0.00 & $2.22 \mathrm{ab}$ & $4.83 \mathrm{bc}$ & $5.45 \mathrm{bc}$ & $5.61 \mathrm{bc}$ \\
\hline $\mathbf{A}_{\mathbf{3}}$ & 0.00 & $1.00 \mathrm{ab}$ & $3.92 \mathrm{c}$ & $4.26 \mathrm{c}$ & $4.26 \mathrm{c}$ \\
\hline $\mathbf{A}_{\mathbf{4}}$ & 0.00 & $0.39 \mathrm{~b}$ & $4.50 \mathrm{bc}$ & $4.50 \mathrm{c}$ & $4.50 \mathrm{c}$ \\
\hline $\mathbf{A}_{\mathbf{1}} \mathbf{N T}_{\mathbf{3}}$ & 0.00 & $3.00 \mathrm{ab}$ & $8.00 \mathrm{a}$ & $8.56 \mathrm{ab}$ & $8.67 \mathrm{ab}$ \\
\hline $\mathbf{A}_{\mathbf{2}} \mathbf{N T}_{\mathbf{2}}$ & 0.00 & $1.61 \mathrm{ab}$ & $4.78 \mathrm{bc}$ & $5.33 \mathrm{bc}$ & $5.33 \mathrm{c}$ \\
\hline $\mathbf{A}_{\mathbf{3}} \mathbf{N T}_{\mathbf{1}}$ & 0.00 & $1.59 \mathrm{ab}$ & $4.13 \mathrm{c}$ & $4.18 \mathrm{c}$ & $4.18 \mathrm{c}$ \\
\hline $\mathrm{K}$ &
\end{tabular}

Keterangan : Angka-angka yang diikuti huruf yang sama pada kolom yang sama, berbeda tidak nyata pada uji DMRT 5\%.

Pada penanaman tebu (Event-5 dan NonTransgenik) dan gulma (teki dan krokot) secara monokultur, kepadatan populasi tidak menekan pertumbuhan vegetatif tebu maupun gulma sampai tahap akhir pengamatan (70 HST). Hal ini menunjukkan bahwa kompetisi intraspesifik antar tebu dan pada gulma belum terjadi sampai umur tanaman 70 HST. Pada penanaman campuran tebu Event-5 dan gulma, perlakuan populasi menekan pertumbuhan vegetatif baik tebu maupun gulmanya. Penurunan peubah vegetatif tebu yang meliputi tinggi tanaman dan jumlah anakan nampak jelas pada saat tanaman tebu mencapai umur 42 HST. Penurunan yang terjadi menurut Tarmani, dkk (1984) dimungkinkan sebagai akibat dari pertumbuhan gulma utama tebu yang mencapai tingkat maksimum saat tanaman tebu mencapai umur 7-12 minggu. Penurunan komponen vegetatif ini menunjukkan adanya kompetisi interspesifik antara tebu Event-5 terhadap gulma dan tebu Non-transgenik.

\section{Kemampuan Kompetisi Tebu Event-5}

Kemampuan kompetisi tanaman dapat diduga secara tidak langsung dengan menggunakan bobot kering tanaman dari suatu percobaan dengan sistem penanaman monokultur dan sistem campuran pada masing-masing jenis tanaman, (Spitters dan van Bergh, 1982). Pendugaan kemampuan kompetisi antara tebu Event-5 yang ditanam bersama dengan gulma dan tebu NonTransgenik pada percobaan ini ditunjukkan oleh persentase penurunan berat kering dari perbandingan system monokultur dan campuran.

Dari hasil analisa menunjukkan bahwa persentase penurunan berat kering tebu Event-5 (A:X; A:Y; dan A:NT) lebih besar dibandingkan dengan kompetitornya (Gambar 1), pada sistem tanam campuran dalam kombinasi populasi yang berbeda dengan gulma teki (X:A), gulma krokot (Y:A) dan tebu Non-transgenik (NT:A). Data tersebut memperlihatkan bahwa penurunan berat kering tebu Event-5 (Gambar 1a, 1c dan 1e) lebih drastis dibandingkan penurunan berat kering gulma teki, krokot dan tebu Non-transgenik (Gambar 1b, 1d dan 1f) pada sistem campuran. Hal ini mengindikasikan bahwa pada populasi kepadatan tanaman yang sama (6:6), kemampuan kompetisi tebu Event-5 lebih rendah dibandingkan dengan gulma teki, gulma krokot dan tebu Nontransgenik.

\section{Koefisien Kesesakan Relatif (Relative Crowding coeficient)}

Koefisien kesesakan relatif merupakan suatu nilai yang menunjukkan tolak ukur kemampuan bersaing suatu tanaman. Jenis tumbuhan yang memiliki koefisien kesesakan relatif tinggi menunjukkan kemampuannya yang tinggi dalam persaingan (Utomo et. al., 2007).

Berdasarkan hasil perhitungan berat kering tebu dan gulma dari data percobaan replacement 
series, diperoleh hasil koefisien kesesakan relatif

Nilai koefisien kesesakan relatif tersebut diperoleh dari proporsi penanaman yang berimbang dari tebu Event-5 dan gulma dan atau dari tebu Event-5 dan tebu Non-Transgenik. Hasil analisa menunjukkan bahwa nilai koefisien kesesakan relatif tebu Event$5 \quad\left(\mathrm{~K}_{\mathrm{ax}}=1.122\right)$ hampir sama dengan nilai seperti yang ditampilkan pada Gambar 2. kesesakan dari gulma teki $\left(\mathrm{K}_{\mathrm{xa}}=1.103\right)$, hal ini mengindikasikan bahwa kompetisi antara tebu Event-5 dan gulma teki terjadi secara berimbang (Gambar 2a). Sebaliknya gulma teki mendominasi kompetisi terhadap tebu Non-transgenik, yang ditunjukkan oleh nilai koeffisien kesesakan tebu Non-transgenik yang lebih kecil daripada gulma teki (Gambar 2c).
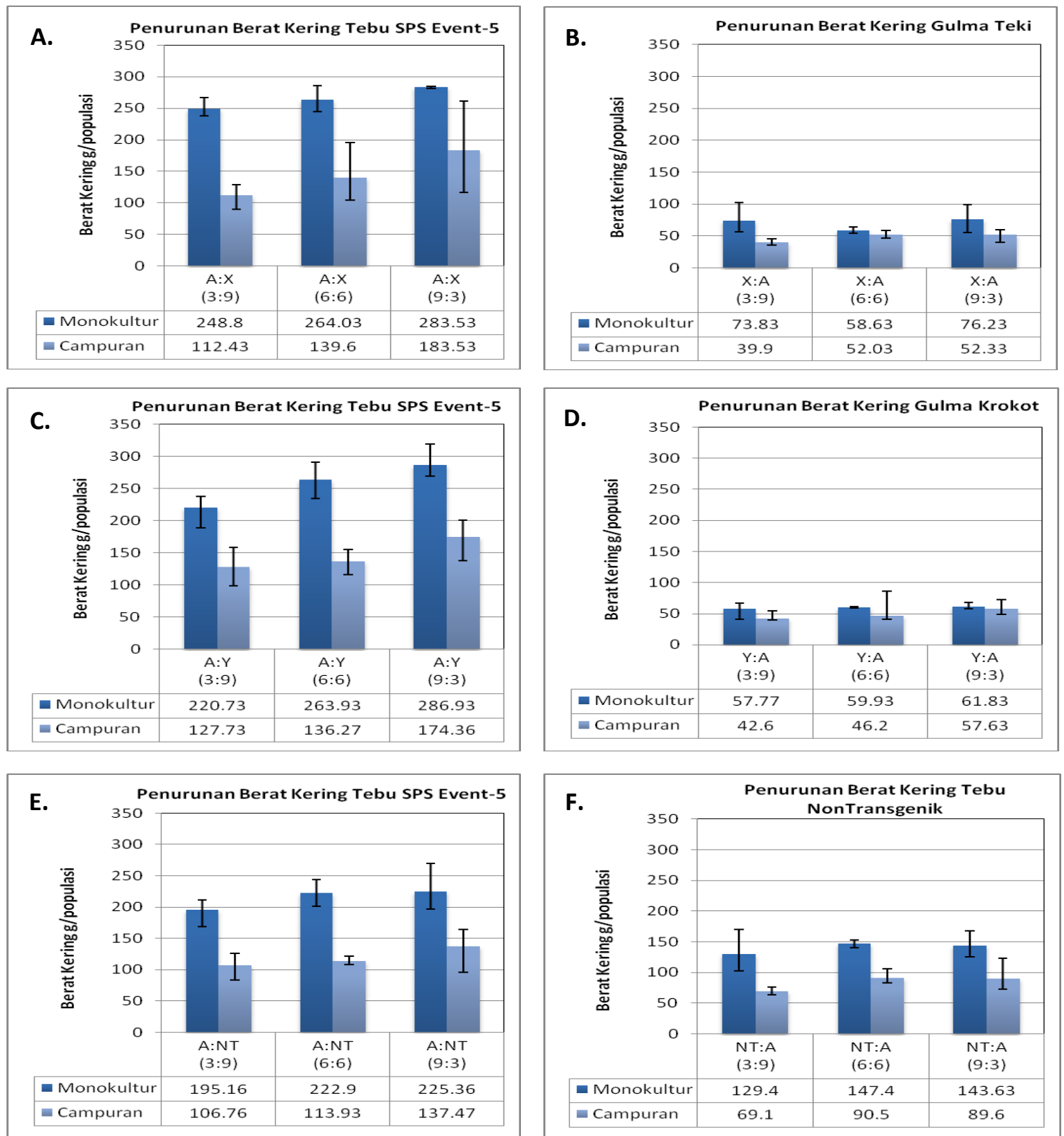

Gambar 1. Grafik penurunan bobot kering antara tebu Event-5 (A) terhadap gulma teki (X), gulma krokot (Y) dan tanaman non-transgenik (NT) yang ditanam secara monokultur dan campuran (replacement series). 
(a)

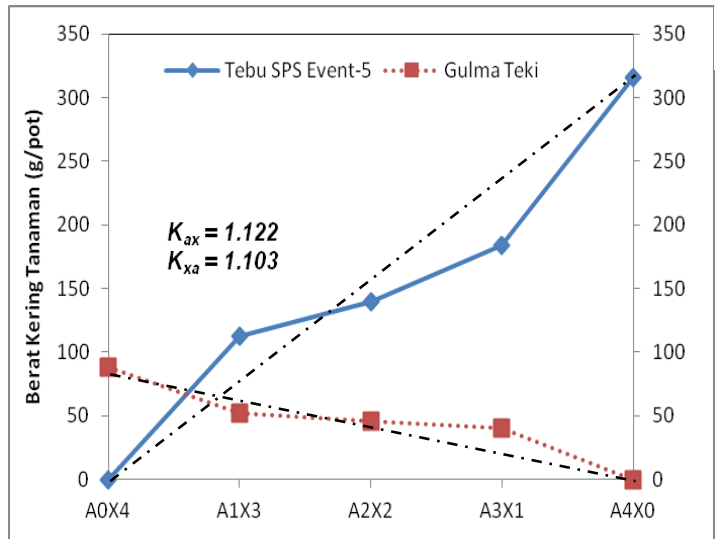

(c)

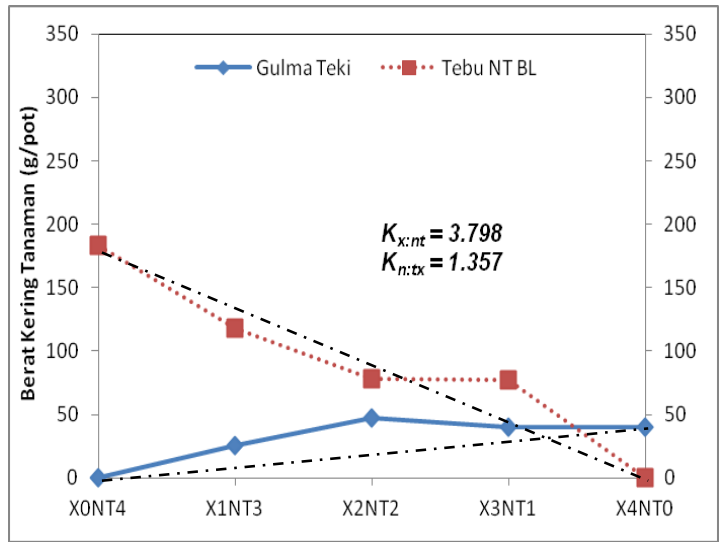

(e)

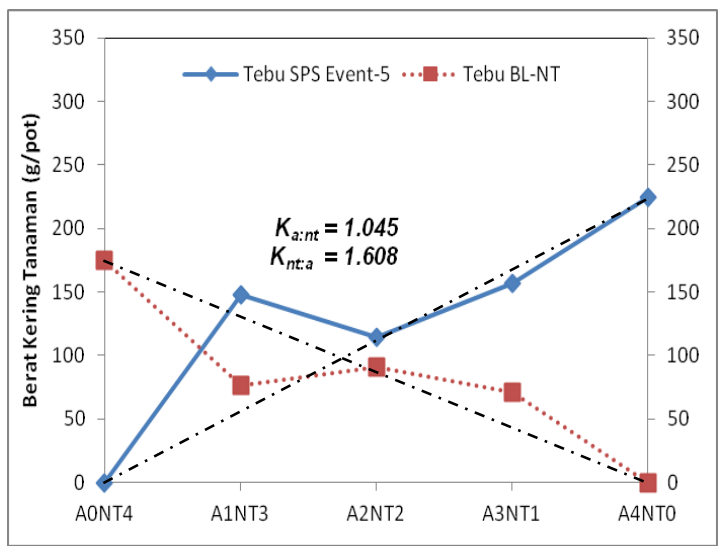

(b)

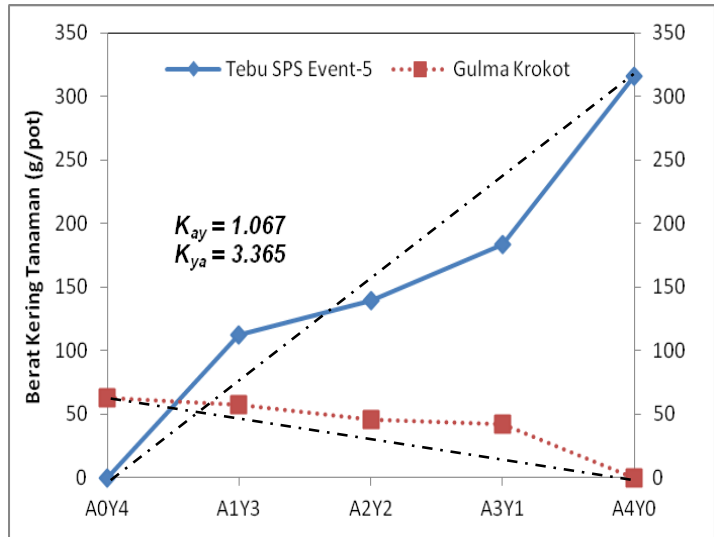

(d)

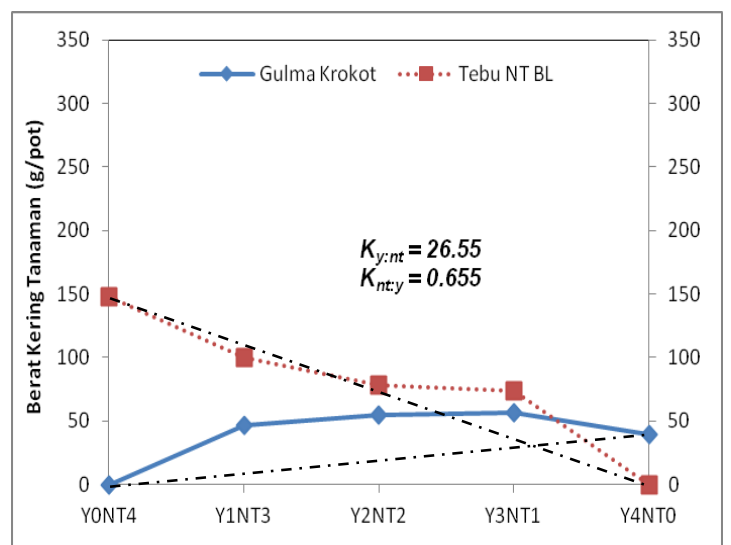

Gambar 2. Hubungan bobot kering dan kepadatan tanaman pada percobaan kompetisi dengan metode replacement series antara tanaman tebu Event-5 (A), tebu Non-Transgenik (NT), gulma teki (X), dan gulma krokot (Y) pada umur tanaman 70 HST.

Pada gulma krokot dan tebu Non-transgenik yang berkompetisi dengan tebu Event-5 memiliki koefisien kesesakan relatif lebih tinggi $\left(\mathrm{K}_{\mathrm{ya}}=\right.$ 3.365 dan $\left.\mathrm{K}_{\text {nt:a }}=1.608\right)($ Gambar $2 \mathrm{~b}$ dan $2 \mathrm{e})$, hal ini menunjukkan bahwa tebu Event-5 kalah bersaing dari gulma krokot dan tebu Nontransgenik sampai umur 70 HST. Jika dibandingkan kemampuan kompetisi antara tebu Event-5 dan tebu Non-transgenik terhadap gulma krokot, tebu Event-5 lebih mampu berkompetisi terhadap gulma krokot dibandingkan tebu Nontransgenik yang ditunjukkan dari nilai koefisien kesesakan relatif tebu Non-transgenik lebih rendah $\left(\mathrm{K}_{\mathrm{nt}: \mathrm{y}}=0.655\right)$ dari nilai koefisien relatif tebu 
Event-5 terhadap krokot $\left(\mathrm{K}_{\mathrm{ay}}=1.067\right)($ Gambar $2 \mathrm{~b}$ dan $2 \mathrm{e}$ ).

Nilai koeffisien kesesakan relatif dari tebu Event-5 secara keseluruhan lebih rendah dari nilai koefisien kesesakan tebu non-transgenik dan gulma teki dan krokot. Hal tersebut mengindikasikan bahwa tebu Event-5 lebih rendah kemampuan berkompetisinya dibandingkan dengan tebu non-transgenik dan jenis gulma utamanya.

Berdasarkan hasil perhitungan berat kering tebu dan gulma dari data percobaan replacement series, diperoleh hasil koefisien kesesakan relatif seperti yang ditampilkan pada Gambar 2. Nilai koefisien kesesakan relatif tersebut diperoleh dari proporsi penanaman yang berimbang dari tebu Event-5 dan gulma dan atau dari tebu Event-5 dan tebu Non-Transgenik. Hasil analisa menunjukkan bahwa nilai koefisien kesesakan relatif tebu Event$5 \quad\left(\mathrm{~K}_{\mathrm{ax}}=1.122\right)$ hampir sama dengan nilai kesesakan dari gulma teki $\left(\mathrm{K}_{\mathrm{xa}}=1.103\right)$, hal ini mengindikasikan bahwa kompetisi antara tebu Event-5 dan gulma teki terjadi secara berimbang (Gambar 2a). Sebaliknya gulma teki mendominasi kompetisi terhadap tebu Non-transgenik, yang ditunjukkan oleh nilai koeffisien kesesakan tebu Non-transgenik yang lebih kecil daripada gulma teki (Gambar 2c).

Pada gulma krokot dan tebu Non-transgenik yang berkompetisi dengan tebu Event-5 memiliki koefisien kesesakan relatif lebih tinggi $\left(\mathrm{K}_{\mathrm{ya}}=\right.$ 3.365 dan $\left.\mathrm{K}_{\mathrm{nt:a}}=1.608\right)($ Gambar $2 \mathrm{~b}$ dan $2 \mathrm{e})$, hal ini menunjukkan bahwa tebu Event-5 kalah bersaing dari gulma krokot dan tebu Nontransgenik sampai umur 70 HST. Jika dibandingkan kemampuan kompetisi antara tebu Event-5 dan tebu Non-transgenik terhadap gulma krokot, tebu Event-5 lebih mampu berkompetisi terhadap gulma krokot dibandingkan tebu Nontransgenik yang ditunjukkan dari nilai koefisien kesesakan relatif tebu Non-transgenik lebih rendah $\left(\mathrm{K}_{\mathrm{nt}: \mathrm{y}}=0.655\right)$ dari nilai koefisien relatif tebu Event-5 terhadap krokot $\left(\mathrm{K}_{\mathrm{ay}}=1.067\right)($ Gambar $2 \mathrm{~b}$ dan $2 \mathrm{e}$ ).

Nilai koeffisien kesesakan relatif dari tebu Event-5 secara keseluruhan lebih rendah dari nilai koefisien kesesakan tebu non-transgenik dan gulma teki dan krokot. Hal tersebut mengindikasikan bahwa tebu Event-5 lebih rendah kemampuan berkompetisinya dibandingkan dengan tebu non-transgenik dan jenis gulma utamanya.

Pendugaan kemampuan kompetisi yang terjadi melalui perhitungan nilai koefisien kesesakan relatif memberikan hasil bahwa tebu Event-5 mampu bersaing dengan gulma teki, namun tidak mampu bersaing dengan gulma krokot dan tebu Non-transgenik (Gambar 2).
Bobot kering tebu Event-5 dan gulma per pot meningkat seiring dengan semakin rendahnya jumlah populasi kompetitor pada tebu dan gulma. Diagram replacement series dari berat kering kedua tanaman yaitu tebu Event-5 dan gulma (teki dan krokot) menunjukkan bahwa berat kering gulma teki dan krokot lebih tinggi dari kompetitornya. Hal ini ditunjukkan oleh bentuk kurva cembung dari gulma teki dan krokot (Gambar 2a, 2c dan 2d). Walck et al. (1999) dan Park et al. (2003) menyatakan bahwa kurva cembung yang dihasilkan dari analisis koeffisien kesesakan relatif dari Salidago sp. antara spesies endemik terhadap eksotis menunjukkan kompetisi intraspesifik tanaman eksotis lebih besar dari interspesifiknya. Sejalan dengan pernyataan tersebut, hasil penelitian ini mengindikasikan bahwa kompetisi intraspesifik yang terjadi pada gulma (teki dan krokot) yang disini bertindak sebagai tanaman endemik, lebih besar dari kompetisi interspesifik saat ditumbuhkan bersamasama dengan tebu Event-5. Sebaliknya kurva cekung yang dibentuk oleh tebu Event-5 saat ditumbuhkan dengan kompetitor dalam proporsi yang lebih kecil menunjukkan bahwa kompetisi interspesifik yang terjadi pada tebu saat ditumbuhkan dengan gulma lebih besar daripada kompetisi intraspesifik antar tebu. Selanjutnya, diagram replacement series yang dibentuk oleh gulma teki dan krokot terhadap tebu Event-5 dan Non-Transgenik menunjukkan bahwa gulma teki dan krokot bertindak sebagai aggresor atau mempunyai potensi invansif atas kedua jenis tanaman tebu tersebut (Gambar 2b, 2c, dan 2d).

Diagram replacement series dari berat kering antara tebu Event-5 dan tebu Non-transgenik menunjukkan bahwa tebu Event-5 masih mampu bersaing dengan besarnya jumlah populasi kompetitor (tebu Non-Transgenik), namun kompetisi selanjutnya menyebabkan berat kering tebu Event-5 berkurang dari berat optimumnya (Gambar 2e). Penurunan berat kering tebu Event-5 menghasilkan nilai koefisien kesesakan relatif yang lebih rendah dari kompetitornya yaitu tebu Non-Transgenik. Hasil ini menunjukkan bahwa tebu Event-5 memiliki kemampuan bersaing lebih rendah terhadap tebu Non-transgenik, dan gulma utamanya, serta mengindikasikan bahwa tebu Event-5 tidak berpotensi sebagai gulma.

\section{KESIMPULAN}

1. Peningkatan kepadatan populasi tebu (Event-5 dan Non-Transgenik) dan gulma (teki dan Krokot) pada sistem monokultur tidak berpengaruh pada tinggi tanaman dan jumlah anakan tebu maupun gulma.

2. Penurunan tinggi tanaman dan jumlah anakan 
pada tebu (Event-5 dan Non-Transgenik) dan gulma (teki dan Krokot) yang ditanam dengan sistem campuran merupakan pengaruh adanya kompetisi interspesifik antara tebu dan gulma.

3. Daya kompetisi tebu Event-5 terhadap kompetitornya lebih rendah dibandingkan dengan daya kompetisi tebu Non-Transgenik dan kedua gulma utamanya (teki dan krokot), yang ditunjukkan dari nilai koefisien kesesakan relatifnya yang lebih rendah dari kompetitornya.

4. Tebu Event-5 memiliki kemampuan bersaing lebih rendah dari kompetitornya sehingga tidak berpotensi sebagai gulma.

\section{UCAPAN TERIMA KASIH}

Penelitian ini didanai PT. Perkebunan Nusantara XI melalui Subbidang penelitian dan pengembangan. Terima kasih pada Kebun Bibit Tebu Jatiroto, Lumajang (P. Deni), yang telah menyediakan bahan tanam (budchip) tebu PRG.

\section{DAFTAR PUSTAKA}

Awodoyin RO., and Ogunyemi S. 2008. Competitive Ability of Sickepod (Senna obtusifolia L) in combination with Chromolaena odorata (L) K \& R and Euphorbia heterophylla L. Tropical Agricultural Research and Extension 11, $p: 25-30$.

De Wit CT. 1960. On Competition. Versl. Landbouwk. 66 (8). Wageningen. The Netherlands. $82 \mathrm{pp}$.

Gioria, M. and Bruce, AO. 2014. Resource competition in plant invasions: emerging patterns and research needs. Front Plant Sci. 5:501-510.

Gordberg, DE. and Barton, M. 1992. Patterns and consequences of interspecific competition in natural communities: a review of field experiments with plants. American Naturalist 139, p 771-801.

Islam, FM. and Karim, SMR. 2003. Effect of population density of Echinochloa crusgalli and Echinochloa colona on Rice. Proceeding $19^{\text {th }}$ Asia-Pacific Weed Science Society Conference. Weed Science of Philippines. Manila. Vol. 1, $p: 275-280$.

Mark, RM, Simberloff D., Lonsdale WM, Evans H, Clout M, and Bazzaz FA. 2000. Biotic invasions: causes, epidemiology, global consequences, and control. Ecological Applications 10: 689-710.
Pantone, JD. 1995. Replacement series analysis of the competitive interaction between a weed and a crop as influenced by a plant parasitic nematode. Fundam. appl.Nematol. 18(1). p:81-85.

Park SE., Benjamin LR., and Watkinson, AR. 2003. The theory and application of plant competition models: an agronomic perspective. Ann Bot. 92 (6): 741-748.

Riches, CR., and Valverder, BE, 2002. Agricultural and biological diversity in Latin America: implications for development, testing, and commercial crops. Weed Technol. 16: 200-214.

Sandhi FV., Guntoro D. 2009. Studi Kompetisi Antara Gulma Echinochloa crus-galli dan Tanaman padi (Oryza sativa L.) dengan Pendekatan Replacement Series. Jurnal Institute Pertanian Bogor 3(1).

Sitompul, SM., Guritno B. 1995. Analisis Pertumbuhan Tanaman. Cetakan Pertama. Gadjah Mada Univervcity Press. Bulaksumur, Yogyakarta. 412 pp.

Spitters, CJT., and Van den Bergh JP. 1982. Competition between crop and weeds. In: Holzmer W.. Numata, M. (eds). Niology and ecology of Weeds. p: 137-148.

Tarmani. P, Darmanto. H dan Agresiana. M. 1984. Gulma di Kebun Tebu di Sumatera Utara. Prosiding Pertemuan Teknis Tengah Tahunan II Lahan Kering di Luar Jawa Tahun 1984. Pasuruan. p: 116-120.

Utomo B., Kusmana C., Tjitrosemito S., Nur Aidi M. 2007. Kajian Kompetisi Tumbuhan Eksotik Yang Bersifat Invasif Terhadap Pohon Hutan Pegunungan Asli Taman Nasional Gunung Gede Pangrango. Jurnal Manajemen Hutan Tropika 13(1 )p: 1-12.

Walck, LJ., Baskin, MJ., Baskin CC. 1999. Relative Competitive Ability and Growth Characteristics of A Norrowly Endemic and A Geographically Widespread Solidago Spesies (Asteraceae). America Journal of Botany 86(6), p: 820-828.

$\mathrm{Xu}, \mathrm{BC}$., Xu, WZ., Huang J., Shan, L., Li, FM. 2011. Biomass allocation, relative competitive ability and water efficiency of two dominant species in semiarid Loess Plateau under water stress. Plant Sci. 181(6). p: 644-651. 